УДК 616-083.98 616

\title{
ОБУЧЕНИЕ ПОДРОСТКОВ НАВЫКАМ ПЕРВОЙ ПОМОЩИ КАК ФАКТОР ПОВЫШЕНИЯ БЕЗОПАСНОСТИ
}

\author{
Подопригора Дмитрий Владимирович \\ МБОУ Лицей №15 ГО \\ Научный руководитель: Ловчикова Ирина Андреевна \\ ассистент кафедры симуляционного обучения \\ ФГБОУ ВО «ВГМУ им. Н.Н. Бурденко»
}

\begin{abstract}
Аннотация: В представленной работе обоснована необходимость обучения старшеклассников навыкам первой помощи. Анализируется готовность учеников старших классов общеобразовательной школы к оказанию первой помощи, актуальность внедрения контекстных методик обучения для повышения эффективности усваивания практических навыков первой помощи. Приведен опыт использования контекстных методов в обучении подростков мероприятиям первой помощи.

Ключевые слова: Первая помощь, контекстные методы обучения, подростки, общеобразовательная школа, внезапная смерть, всемирная организация здравоохранения (ВО3).
\end{abstract}

\section{TEACHING TEENS FIRST AID SKILLS AS A SAFETY FACTOR}

\section{Podoprigora Dmitry Vladimirovich Lovchikova Irina Andreevna}

\begin{abstract}
The presented paper substantiates the need to teach first aid skills to secondary school students. The article analyzes the readiness of secondary school students to provide first aid, the relevance of the introduction of contextual teaching methods to improve the efficiency of mastering practical first aid skills. The experience of using contextual methods in teaching teens first aid measures is given.

Key words: First aid, contextual teaching methods, teens, secondary school, sudden death, World Health Organization (WHO).
\end{abstract}




\section{ВСЕРОССИЙСКИЕ НАУЧНЫЕ ЧТЕНИЯ

XXI век - время высоких технологий, сверхскоростей, бесконечного потока информации. Расплатой за научно-техническое развитие становится потеря ключевой потребности человека в собственной безопасности. Техногенные и природные катастрофы, уровень экстремизма и психологической напряженности в обществе, постоянный стресс - та среда, в которой живет современный человек. Агрессивный окружающий мир значительно повышает вероятность столкнуться с жизнеугрожающим состоянием для обывателя, не имеющего отношения к медицине. Конечно, хотелось бы рассчитывать на то, что в случае необходимости рядом окажется человек, который всё знает и умеет. Особенно, если ты сам - ребенок. Но, как известно, si vis pacem, para bellum (хочешь мира, готовься к войне, лат.) [1]. К сожалению, достаточно событий, связанных с жизнеугрожающими состояниями с участием детей в таком, казалось бы, безопасном месте, как школа, уже случились и могут повториться. Даже без учета происшествий, связанных с экстремистской деятельностью и большим количеством пострадавших, статистика внезапной смерти на обычном уроке физкультуры в обычной общеобразовательной школе выглядит серьезно. По информации, которую обнародовала министр образования и науки РФ О.Ю. Васильева 9 октября 2017 года на заседании Комитета Совета Федерации по науке, образованию и культуре, в России на уроках физкультуры за 20162017 учебный год погибло 211 школьников [2]. Таким образом, сложно переоценить потребность обучения школьников навыкам первой помощи. На данный момент школьники получают информацию о первой помощи в рамках предмета «Основы безопасности жизнедеятельности» (ОБЖ).

Целью данной работы стало определение влияния методов обучения (рутинный и контекстный) на степень готовности учеников старших классов общеобразовательных средних учебных заведений к оказанию первой помощи на месте происшествия.

В качестве материалов и методов использовались: анкетирование, статистическая обработка.

В рамках настоящей работы было проведено анкетирование 100 учащихся старших классов (в возрасте 16-18 лет) общеобразовательных школ города Воронеж. Анкета содержала нижеприведенные вопросы (табл.1). 
Таблица 1

Вопросы анкеты

\begin{tabular}{|c|l|}
\hline 1 & Готов ли ты оказать первую помощь пострадавшему? \\
\hline 2 & $\begin{array}{l}\text { Первый шаг алгоритма первой помощи пострадавшему на месте } \\
\text { происшествия? }\end{array}$ \\
\hline 3 & $\begin{array}{l}\text { Как понять, надо ли приступать к сердечно-легочной } \\
\text { реанимации? }\end{array}$ \\
\hline 4 & $\begin{array}{l}\text { Как проверить, дышит ли человек? } \\
\text { Какие мероприятия первой помощи надо провести, если человек } \\
\text { без сознания, дышит? }\end{array}$ \\
\hline 6 & $\begin{array}{l}\text { Какие мероприятия первой помощи надо провести, если человек } \\
\text { подавился? }\end{array}$ \\
\hline 7 & $\begin{array}{l}\text { Какие мероприятия первой помощи надо провести, если человек } \\
\text { получил ожог пламенем? }\end{array}$ \\
\hline 8 & Что такое АНД? \\
\hline 9 & $\begin{array}{l}\text { Куда и как ставить руки для проведения компрессий грудной } \\
\text { клетки? }\end{array}$ \\
\hline 10 & Глубина и частота компрессий грудной клетки? \\
\hline
\end{tabular}

На первый вопрос небольшая часть респондентов (15\%) ответили положительно. На вопросы 2-10 не было получено ни одного правильного ответа. После анкетирования силами сотрудников ФГБОУ ВО «ВГМУ им. Н.Н. Бурденко» был проведен марафон по оказанию первой помощи в рамках программы «KIDS SAVE LIVES», являющейся проектом Всемирной организации здравоохранения (2015 год) по масштабному обучению детей старше 12 лет навыкам сердечно-легочной реанимации. Мероприятие было организовано на базе МБОУ Лицей № 15 ГО г. Воронеж. Со стороны ВГМУ был организован начальником Мультипрофильного аккредитационносимуляционного центра Подопригорой Анной Владимировной, доцентом кафедры анестезиологии и реаниматологии Чурсиным Александром Александровичем и со стороны Лицея директором Малышевым Артемом 299 
Станиславовичем, заместителем директора по воспитательной работе Тюльпиной Натальей Игорьевной.

В обучении использовались возможности мультипрофильного аккредитационно-симуляционного центра (МАСЦ) ВГМУ им. Н.Н. Бурденко [3] и личные наработки преподавателей центра в плане контекстных методов обучения [4]. Мастер-класс начали с короткой проблемной лекции о жизнеугрожающих состояниях, требующих оказания первой помощи. Контекстный подход в данном случае выражался в участии школьников в дискуссии с лектором, обсуждении реальных случаев, резонансных событий. После был проведен собственно мастер-класс в виде четырехступенчатого изложения алгоритма первой помощи на месте происшествия $\mathrm{c}$ использованием модульного манекена Resusci® Anne QCPR, манекенатренажера Choking Charlie и учебного автоматического наружного дефибриллятора (АНД), имеющихся в оснащении МАСЦ ВГМУ им. Н.Н. Бурденко. Затем в виде спортивной эстафеты школьники оказывали первую помощь на нескольких этапах: при попадании инородных тел в верхние дыхательные пути грудным детям, детям дошкольного возраста, взрослым, демонстрировали правильность алгоритма реанимации для детей "CHECK-CALL-COMPRESS», проводили сердечно-легочную реанимацию. По окончанию был проведен дебрифинг с разбором допущенных участниками ошибок. Мастер-класс был завершен адаптационной игрой с заранее разработанным сценарием, требующим от слушателей активного участия и применения навыков оказания первой помощи. Помимо указанного выше оборудования, для большей зрелищности использовали искусственную кровь, имитаторы травм. Всего в марафоне приняли участие более 100 школьников из старших классов. В качестве судей выступили участники команды МАСЦ ВГМУ «REANIME» - студенты старших курсов ВУЗа.

На следующий день после мероприятия было проведено повторное тестирование с использованием указанной выше анкеты среди школьниковучастников марафона. Готовность к оказанию первой помощи изъявили уже $80 \%$ респондентов. На вопросы 2-10 правильными были $100 \%$ ответов, что говорит о высокой суточной выживаемости полученных навыков. Для понимания годовой выживаемости знаний планируется проведение анкетирования участников марафона в 2022 году. 


\section{ВСЕРОССИЙСКИЕ НАУЧНЫЕ ЧТЕНИЯ \\ ИМЕНИ АКАДЕМИКА А.Д. САХАРОВА}

Полученные данные позволяют сделать вывод о недостаточной готовности старшеклассников к оказанию первой помощи, что связано с применением рутинных методов в обучении соответствующим навыкам в рамках предмета Основы безопасности жизнедеятельности. Даже при максимальных стараниях со стороны преподавателей предмета, школьники не воспринимают первую помощь как первостепенно необходимые знания. Именно поэтому формирование устойчивых навыков оказания первой помощи и положительной мотивации к их применению при необходимости требует иного подхода. Результаты проведенного исследования показали высокую эффективность применения контекстных методов обучения по оказанию первой помощи среди старшеклассников: мастер-классы, проблемные лекции, адаптационные игры. Личное активное участие, соревновательный момент, реалистичная фабула игровых мероприятий, использование эффекта театрализованного представления с неминуемым благополучным завершением - те отличительные свойства контекстного обучения, которые в значительной мере могут влиять на эффективность обучающих программ, особенно связанных с получением практических навыков [5]. Контекстные методики позволяют сформировать позитивную внутреннюю мотивацию и к обучению, и к готовности оказания первой помощи у старшеклассников, что особенно важно для формирования безопасной среды в стенах средней школы.

\section{Список литературы}

1. Оборона государственная // Военная энциклопедия : [в 18 т.] / под ред. В. Ф. Новицкого ... [и др.]. - СПб. ; [М.] : Тип. т-ва И. Д. Сытина, $1911-1915$.

2. ИССЛЕДОВАНИЕ СЛУЧАЕВ СМЕРТИ ШКОЛЬНИКОВ НА УРОКАХ ФИЗКУЛЬТУРЫ В РОССИИ Ж.В. Гудинова, Ю.В. Жаркова № 1 (78), Том 15, 2019 Академический журнал Западной Сибири стр 29 - 33

3. Боев Д.Е., Чурсин А.А., Подопригора А.В., Боев С.Н., Ловчикова И.А., Вислова О.П., Сергеева О.С., Жуков А.А. Профориентационная работа со школьниками неотъемлемая часть работы мультипрофильного аккредитационно-симуляционного центра. Виртуальные технологии в медииине. 2021;1(3):126-127. https://doi.org/10.46594/2687-0037_2021_3_1324 
4. Есауленко И.Э. Теория и методика обучения в высшей медицинской школе: Учебное пособие / И.Э. Есауленко, А.Н. Пашков, И.Е. Плотникова. 2-е изд., исправ. и доп. - Воронеж, ВГМА, 2011. - С. 166-175.

5. Вербицкий А.А. Контексты содержания образования : Монография / А.А. Вербицкий, Т.Д. Дубовицкая ; М-во образования Рос. Федерации. Моск. гос. открытый пед. ун-т им. М.А. Шолохова. - М. : Альфа, 2003. - 80 с. : ил., табл.; 21 см.; ISBN 5-8288-0569-X (в обл.) 